\title{
Sürdürülebilir Bir Kentleşme Yaklaşımı Olarak, Ekolojik Planlama ve Eko-Kentler
}

\author{
Hayriye Eylül Kaya ${ }^{1}$ \\ ORCID: 0000-0003-3287-4493
}

\author{
Arzu Taylan Susan ${ }^{2}$ \\ ORCID: 0000-0001-5718-8794
}

Öz

Ekonomi ve teknolojinin gelişmesi, kentlere göçü arttırmış ve kentlerin hızlı bir şekilde büyümelerine neden olarak büyüme şekillerinde değişiklik yaratmıştır. Artan nüfusun ihtiyaçların karşılamak üzere, yayılarak ve saçaklanarak büyüyen kentler, bir yandan çevrelerindeki tarım topraklarının yitirilmesine, diğer yandan ise bireysel araç kullanımının yaygınlaşarak karbon ayak izinin artmasına ve iklim değişikliğine neden olmaktadır. Bu bağlamda, sinırl doğal kaynakların korunması ve gelecek nesillere aktarılmasının giderek daha fazla hayati önem taşıdı̆̆ görülmekte, kentlerin kontrolsüz ve hızl gelişmesinin önüne geçmek için sürdürülebilir kentleşme yaklaşımlarına ihtiyaç duyulmaktadır. Sürdürülebilir kentler, aynı zamanda, gelecek nesillerin sağlıklı yaşam çevreleriyle karşılaşacağı yaşanabilirliği yüksek yerlerdir. Bu nedenle, çeşitli ülkelerde ortaya çıkan Akıllı Büyüme, Yeşil Kentleşme, Yeni Şehircilik ve Ekolojik Planlama gibi sürdürebilirliği merkezine alan yeni kentleşme akımları ve yaklaşımları tüm dünyada yayılmaktadır. Bu yaklaşımların kentsel büyümeye ve biçime ilişkin geliştirdiği ilkeleri gözden geçiren bu makale, bunlarm ortak noktasın oluşturan ve uygulama politikalarmı da içeren ekolojik planlama yaklaşımına odaklanmaktadır. Makale, ekolojik planlamada kullanılan kavramlar, ilkeler ve modelleri tarihsel süreçte gelişimiyle beraber irdelemektedir. Makalede sürdürülebilir ve ekolojik kentlerin planlamasına yönelik ilkeleri ve modelleri içeren bulgularn, Türkiye'de eko-kent projelerinin uygulanması ve mevcut kentsel alanlarn ekolojik ve sürdürülebilir yönde değişimi için planlama süreçlerine ve politika yapıcılara katkıda bulunacaktır.

Anahtar Kelimeler: Ekoloji, Sürdürülebilirlik, Doğal Kaynaklar, Ekolojik Planlama Yaklaşımları, Eko-kent

\footnotetext{
${ }^{1}$ Şehir Plancısı, Meram Belediyesi, E-mail: eylulkonyalioglu@gmail.com

${ }^{2}$ Dr. Öğr. Üyesi, Bursa Teknik Üniversitesi E-mail: arztaylan@gmail.com

idealkent @ Kent Araştırmaları Dergisi (Journal of Urban Studies) 


\title{
Ecological Planning and Eco-Cities As a Sustainable Urbanization Approach
}

\author{
Hayriye Eylül Kaya ${ }^{3}$ \\ ORCID: 0000-0003-3287-4493
}

\author{
Arzu Taylan Susan 4 \\ ORCID: 0000-0001-5718-8794
}

\begin{abstract}
The economic and technological progresses have changed urban development pattern by increasing rural-to-urban migration, while meeting the needs of the growing population led to rapid growth of cities through sprawls. In this context, protection of limited natural resources and their transfer into future generations become increasingly essential, when sustainable urbanization approaches are required to prevent uncontrolled and rapid growth of cities. Thus, sustainable urbanization movements and approaches such as Smart Growth, Green Urbanization, New Urbanism and Ecological Planning, which have been launched in various countries, have spread around the world. Reviewing certain principles of these movements on the urban growth and urban form, the article focuses on the common point of these approaches, i.e. the ecological planning, which includes also certain planning principles and implementation policies. Then, the article examines the concepts, principles and models used in ecological planning with their development in the historical process. The findings of this article, which cover the principles and models for planning the sustainable and ecological cities, will not only contribute to planning processes and policy makers for the development and implementation of eco-cities, but also to transform the existing urban areas toward ecological and sustainable environs in Turkey.
\end{abstract}

Keywords: Ecology, Sustainability, Natural Resources, Ecological Planning Approaches, Eco-city

\footnotetext{
${ }^{3}$ Urban Planner, Municipality of Meram, E-mail: eylulkonyalioglu@gmail.com

${ }^{4}$ Asts. Prof., Bursa Technical University, E-mail: arztaylan@gmail.com

idealkent @ Kent Araştırmaları Dergisi (Journal of Urban Studies) 


\section{Giriş}

Kentler, tarih boyunca fiziksel ve sosyal çevrenin etkileşmesiyle değişimlere sahne olmuştur. 17. ve 18.yy'da endüstri devrimi sonrasında sanayileşmeye eşlik eden kentleşmenin yaşandığı Batı ülkelerinin ekonomik büyüme ve kalkınma modellerini, 20. yy'da diğer ülkeler de izlemeye başlamış ve hızlı bir kentleşme sürecine girmişlerdir. Doğanın sınırsız bir kaynak olarak görüldüğü ekonomik büyüme ve kentleşme süreçleri, küreselleşme sonrasi ekonomik yeniden yapılanmanın etkisiyle daha da tetiklenmiştir. Günümüzde, tüm dünyada kentsel alanlarda artan nüfusun tüketim ihtiyacını karşılamak üzere doğal çevreye verilen tahribat insanlığı tehdit eder duruma gelmiştir.

Ekonomik büyüme ve sanayileşmenin doğal çevreye verdiği zarara ilişkin endişeler uluslararası politika alanında ilk defa Stockholm Konferansi'nda (1970) ifade edilmiştir. Doğal çevre ve kaynakların sınırlı olduğu gerçeğiyle yüzleşen dünya toplumu, kısa süre sonra Brundtland Raporu (1987) ile ‘sürdürülebilir kalkınma' yaklaşımını öne sürmüştür. Takip eden süreçte gerçekleşen konferanslar (Rio Zirvesi ve Gündem 21 (1992), BM İnsan Yerleşimleri Konferansi-Habitat II (1996), BM Milenyum Zirvesi (2010), Rio+20 Zirvesi (2012)) ile ekonomik büyüme odaklı kalkınma yerine, doğal çevrenin korunması ve toplumsal gelişmenin sağlanmasını dengeleyen sürdürülebilirlik yaklaşımı önerilmiştir. Uluslararası politikanın bugün devam eden gündeminde ise (Sürdürülebilir Kalkınma Hedefleri (2015), Gündem 2030 (2016) ile Habitat III-Yeni Kentsel Gündem (2016)), tüm dünyada sürekli artan kentleşmenin çevre ve insanlar üzerindeki olumsuz etkileri nedeniyle, kentsel alanlara dikkat çekilmektedir. Kentlerin arazi kullanım kararları ve şehir planlaması yoluyla sürdürülebilir hale getirilmesi gerektiği vurgulanmaktadır.

Nitekim, kentsel yayılma ve saçaklanma ile düzensiz büyüyen kentler, verimli tarım arazileri, sulak alanlar gibi doğal kaynaklara zarar vermekte, genişleyen yerleşim yüzeyi ve yaygınlaşan otomobil kullanımı nedeniyle artan karbon ayak izi ise iklim değişimi gibi küresel ölçekte tehditler ortaya çıkarmaktadır. Bu nedenle, pek çok ülkede uluslararası politika doğrultusunda akıllı büyüme, yeni şehircilik, yeşil bina hareketi, derişik kent, karşıt-kentleşme, yeşil kentler, ekolojik planlama ve eko-kentler gibi sürdürülebilir kentleşme (sustainable urbanization) yaklaşımları ve akımları ortaya çıkmıştır (Chandra, Chhetri, Corcoran, Han , 2013 ; Farr, 2008; Van Kamp et al., 2003).

Ancak, bu yaklaşımlar her ne kadar belirli ülkelerde ortaya çımış olsa da, ülkelerin karşılıklı etkileşim içinde olduğu günümüz küresel dünyasında farklı ülkeler tarafından da uygulanmaktadır. Bu yaklaşımlardan biri olan 
ekolojik kentleşme ise, küresel bir ortak söylem olarak kabul edilmektedir. Türkiye'de de, sürdürülebilir kalkınma ve sağlıklı kentsel gelişme kavramların çeşitli politika belgelerinde yer almaktadır. Bununla beraber, henüz uygulanmış somut örnekler olmamasına rağmen, yerel ve merkezi yönetimler tarafından Eskişehir, Bursa, Konya ve Gaziantep gibi illerde ekoloji odaklı kentsel projeler geliştirilmektedir.

Bu bağlamda, sürdürülebilir kentsel çevrelerin oluşturulması için planlama ve tasarım ilkeleri yanı sıra çevreye ilişkin politikaları irdelemeyi amaçlayan bu makale, öncelikle tüm dünyada yaygınlaşan sürdürülebilir kentleşme yaklaşımlarını gözden geçirmektedir. Makale, daha sonra bu yaklaşımlar arasında -gerek diğerlerinin ortak noktasını oluşturması gerekse uygulama politikalarını da kapsaması nedeniyle- önemli bir yer tutan ekolojik planlama yaklaşımına odaklanmaktadır. Sonuç bölümünde sunulan bulguların tartışması ve değerlendirmesinin, ülkemizde geliştirilmekte olan ekoloji odaklı kent ve kentleşme modellerine ve bu doğrultuda geliştirilecek politikalara katkı sağlayacağı düşünülmektedir.

\section{Sürdürülebilir Kalkınma, Sürdürülebilir Kentler ve Kentleşme}

Tarihsel süreçte kentleşme ve ekonomik kalkınmanın birbirine eşlik etmesi, Batı ülkelerinin 17-18. yy.'larda deneyimlediği Endüstri devrimi ve sonrasında yaşanan sanayileşme süreciyle ortaya çıkmıştır. Tarımsal toplumun kentsel sanayi toplumu ile yer değiştirdiği bu dönemde Batı ülkelerindeki kentler büyük göçlerle büyürken, doğa sınırsız bir kaynak olarak görülmüştür. Bu ekonomik büyüme ve kalkınma modelinin, II. Dünya Savaşı'ndan sonra tüm dünya ülkelerine evrensel bir model olarak gösterilmesiyle, Batı haricindeki ülkeler de çevrenin kirletildiği sanayileşme sürecine katılmakla kalmamış, tarımsal üretim azalırken geçirdikleri hızlı kentleşme süreçleri sonucunda büyük kentsel alanlara sahip olmuşlardır.

Küreselleşme süreciyle girilen ekonomik yeniden yapılanma döneminde ise, küresel rekabet ortamında akışkan sermayeyi kendilerine çekmek isteyen -genellikle ekonomik büyümeyi hedefleyen gelişmekte olan- ülkelerin çevreyi tahrip eden sanayilere ev sahipliği yaptığı görülmektedir. Bir yandan çevreye olan tahribat farklı şekillerde devam ederken, diğer yandan nüfustaki hızlı artışın gıda ihtiyacını karşılamak için yetersiz tarımsal üretim ve temiz su ihtiyacının artması gibi sorunlar giderek artmaktadır. Ancak, günümüzde çevre sorunları küresel boyuta ulaşmış, bir başka deyişle çevreye verilen tahribat bugün insanlığı tehdit eder duruma gelmiştir. 
Salt ekonomik gelişmeye odaklanan kalkınma biçiminin çevreye verdiği zarara dikkat çeken Stockholm Konferansı (1972) uluslararası politika düzeyindeki ilk çevre konferansı olmuştur. Sürdürülebilirlik düşüncesinin temellerinin atıldığı bu konferansta, doğal çevrenin ve kaynakların sınırlı olduğu ve gelecek kuşakların ihtiyaçlarının bugünden düşünülmesi gerektiği belirtilmiştir. Kalkınma ve doğal çevre arasında denge kurma arayışı 1980'lerde Dünya Çevre ve Kalkınma Komisyonu'nun Brundtland Raporu olarak da bilinen 'Ortak Geleceğimiz' adlı raporunda 'sürdürülebilir kalkınma' anlayışı ilk defa ortaya konmuştur. Rapora göre, sürdürülebilir kalkınma, "günümüz ihtiyaçlarının, gelecek kuşakların ihtiyaçlarını karşılama olanaklarından fedakârlık yapılmaksızın karşılanabilmesi süreci" olarak tanımlanmaktadır.

Küresel düzeyde bütün ekosistemleri etkileyen çevresel sorunlara değinen rapor, kalkınmanın sürdürülebilir olmasını, çevre ve ekonomik gelişme arasında denge kurulmasına bağlı kılmaktadır (Kaypak, 2011). Bu bağlamda, sürdürülebilir kalkınma, 1980'li yıllardan başlayarak tüm dünyada, çevre politikalarının belirleyicisi olmakla birlikte, etki alanı çevre ile sınırlı kalmamış, ekonomik ve toplumsal gelişme anlayışlarıyla da bütünleştirilmiştir. Bu nedenle, 'çevre, ekonomi ve toplum' sürdürülebilirlik kavramı içerisinde yer alan üç temel bileşen olarak birbiriyle ilişkili ve birbirini destekleyen nitelikte ele alınmaktadır (Tosun, 2013).

Sürdürülebilir kalkınmanın ekonomiye yaklaşımı, niceliksel bir tutum içindeki ekonomik büyümeyi odağına alan 1960'ların kalkınma yaklaşımlarından farklı olarak, ilerlemenin ve iyileşmenin niteliksel boyutlarını göz önüne alan ekonomik gelişme yaklaşımını benimsemektedir (Özcan, 2007). Diğer yandan, sürdürülebilirlik kavramı çevreye zararlı olabilecek tüm alışkanlık ve hareketlerin sona erdirilmesini öngörmektedir. Çünkü, sürdürülebilirlik temelinde insanın iyiliği doğal kaynaklara bağlıdır (Yazar, 2006).

Sürdürülebilir kalkınma yaklaşımının uluslararası politikada 1980'lerden günümüze kadar uzanan süreçteki toplantılarının (Rio Zirvesi ve Gündem 21, BM İnsan Yerleşimleri Konferansi-Habitat II, BM Milenyum Zirvesi, Rio+20 Zirvesi, Sürdürülebilir Kalkınma Hedefleri , Gündem 2030 ile Habitat III-Yeni Kentsel Gündem) gündemi incelendiğinde, tüm dünyada sürekli artan kentleşme nedeniyle özellikle kentsel alanlara giderek daha fazla dikkat çekildiği görülmektedir. Sürdürülebilir Kalkınma Hedefleri'nin 11.hedefinde şehirlerin ve insan yerleşimlerinin "kapsayıcı, güvenli, dayanıklı ve sürdürülebilir hale getirilmesi" ilkesi yer almaktadır. 
Sürdürülebilir Kalkınma Hedefleri Raporu'nda (2018), bu hedef ile dünyadaki birçok şehirde, hızlı kentleşmenin yönetilmesi, artan nüfusların desteklenmesi, yeterli konut ve altyapının sağlanması, kentsel yayılmanın çevresel etkilerinin ve afetlere karşı savunmasızlığın azaltılması gibi ciddi zorluklarla karşılaşıldığından söz edilmektedir. Bu nedenle, sürdürülebilir kalkınma, kentsel alanlardaki hızlı kentleşmenin yol açtığı sorunlarla baş etmek için, arazi kullanım kararları ve şehir planlaması ile yerel stratejilerin geliştirilmesini gerekli görmektedir (BM,2018).

Nitekim, giderek kalabalıklaşan kentler, çevrelerindeki tarım ve orman alanlarını yok etme ve su kaynaklarını kirletme pahasına kontrolsüz bir şekilde yayılarak büyümektedir. Bugün kentlerde, işyeri-konut arası artan seyahat mesafelerini aşmak için teknolojik gelişmeyle beraber yaygınlaşan fosil yakıt tüketen otomobillerin kullanımı gibi çevreye zarar veren tüketim tarzlarının geliştiği görülmektedir. Ancak, bu yeni yaşam tarzının neden olduğu sorunlar sadece hava kirliliği ve sağlık sorunlarıyla sınırlı kalmamakta, aynı zamanda karbon ayak izinin artması nedeniyle dünya toplumunu küresel iklim değişikliği gibi yeni sorunlarla karşı karşıya bırakmaktadır.

Bu nedenle, 21. yüzyılda değişen ve değişmeye devam eden dünya üzerindeki tüm canlılar için yaşam kaynağı olan doğal çevrenin tüketilmesi ve yitirilmesi kaygısına karşı yeni şehir planlama anlayışları geliştirilmesi zorunlu hale gelmiştir. Sürdürülebilir bir kentin, kentleşme biçiminin ve bu doğrultuda geliştirilecek şehir planlama yaklaşımlarının nasıl olması gerektiğine dair çeşitli görüssler bulunmaktadır.

İyi bir kentin nasıl olması gerektiğine değinen Lynch (1984), hayati (güvenli, uyumlu ve sürdürülebilir), mantıklı (tanımlanabilir, biçimli, uyumlu, şeffaf, okunaklı, gelişebilir ve kayda değer), ustalıkla yönetilebilir, esnek, ulaşılabilir (çeşitli, eşitlikçi, yerel olarak yönetilebilir) ve kontrol edilebilir (ahenkli, güvenilir, sorumlu ve aralıklı olarak serbest) bir kent formundan söz etmekte ve bunların adalet ve dahili verimlilikle sağlanacağını savunmaktadir (Lynch, 1984).

Van Geenhuiisan ve Nijkamp (1994), kent bağlamında sürdürülebilirliği, kentsel sistemin temelini uzun vadede destekleyen çevresel koşullarla beraber yeni bir sosyo-ekonomik ve teknolojik gelişme seviyesine ulaşma potansiyeli olarak tanımlamaktadır. Bu çerçevede, sürdürülebilir kentsel gelişmenin ilkeleri güçlü ekonomi, temiz çevre, toplumsal eşitlik ve katılım olarak siralanabilir.

Eryıldız'a göre (2011) sürdürülebilir bir kent, yaşayanların kendi ihtiyaçlarını karşılarken, şu anda veya gelecekte, diğer insanların yaşam koşullarını 
ve doğal çevredeki biyolojik çeşitliliği tehlikeye atmadığı bir kent olmalıdır. Böyle bir kent, kendisini çevreleyen kırsal alandan güvenle beslenebilmeli ve yenilenebilir enerji kaynaklarıyla kendisini güçlendirebilmelidir. Wheeler (2013) ise sürdürülebilir bir kentin, toplumun tüm bireyleri için rahat, çekici, yeşil, güvenli, insan ölçeğinde, kimlikli ve sağlıklı olması gerektiğini savunmaktadır.

Tosun'a göre (2013) sürdürülebilir kentleşme kavramı, sürdürülebilir kalkınma olgusunun başta çevre olmak üzere, ekonomi, politika, toplumsal yaşam vb. düzlemlerde yaygınlaşması ve bu alanlarda alınan kararlarda ve uygulamalarda temel ilke olarak kabul edilmesine paralel olarak ortaya çıkmıştır. Yazar (2006) sürdürülebilir kentleşmeyi, kentler ve onları çevreleyen kırsal alanlar arasında, ve en küçük kentsel merkezlerden metropoliten alanlara kadar olan tüm insan yerleşimleri arasında bağlantıları sağlayan bir olgu olarak görmektedir.

Sürdürülebilir kalkınmaya yönelik geliştirilecek şehir planlama yaklaşımları Eryıldız'a (2011) göre, yaşam çevrelerini ve doğayı gelecek kuşaklara aktarma hedefine bağlı kalarak, sürdürülebilirliğin ekolojik, ekonomik ve toplumsal boyutlarını ele almalıdır. Wheeler (2013) ise, sürdürülebilir kentlerin planlanması ve yönetiminde, derişik (kompakt) ve etkin arazi kullanımı, daha az motorlu araç kullanımı, erişim kolaylığı, etkin kaynak kullanımı, daha az kirlilik ve atık, doğal sistemlerin restorasyonu, kaliteli barınma ve yaşam çevrelerinin oluşturulması, sağlıklı sosyal ekoloji, yerel kültürün korunması, sürdürülebilir ekonomi, halk katılımının sağlanması gibi faktörlerin göz önüne alınmasını gerekli görmektedir.

Çalışkan (2004) ise, kentlerin sürdürülebilir gelişmesi için, yaya odaklı hareketi kolaylaştırıı kentsel tasarım kodlarının desteklenmesi gerektiğine dikkat çekmektedir. Bunun temel nedeni, sürdürülebilirliğin toplumların enerji bağımlılığının azaltılmasını öncelikli görmesidir. Fosil yakıtların aşırı kullanımı, sera gazı salınımını endişe verici düzeye ulaştırmıştır. Sanayileşmiş toplumlarda toplam enerji tüketiminin ortalama dörtte biri sadece ulaşım sektörüne aittir. Ancak, kent içi seyahatleri azaltmak amacıyla kent içi yoğunlukların ve arazi kullanımında çeşitliliğin arttırılması gibi yaklaşımlar, yaşam kalitesini azaltabilmektedir. 


\section{Sürdürülebilir Kentleşme Akım ve Yaklaşımları}

Sürdürülebilir kalkınma yaklaşımı ile pek çok ülkede sürdürülebilir bir kentin, kentleşme biçiminin ve planlama yaklaşımının nasıl olması gerektiğine dair arayışlar ve yaklaşımlar ortaya çıkmaktadır. Bunlar arasında, Amerika'da ortaya çıkan 'akıllı büyüme' (smart growth), 'yeni şehircilik' (new urbanism) ve 'Yeşil Bina Hareketi' (green building movement) (Farr, 2008), Avrupa'da kullanılan 'derişik kent' (compact city) ve 'yoğunluk arttırılması' ve Avusturalya' da yaygınlaşan 'uydu kentler ile karşıt-kentleşme' gibi sürdürülebilir kentsel büyüme (kentleşme) yaklaşımları geliştirilmekte ve ülke genelinde uygulamaya dönük politikalarla birlikte akımlar şeklinde hayata geçirilmektedir ( Chandra, Chhetri, Corcoran, Han 2013). Bunların dışında, pek çok ülkede ekolojik kentler (eco cities), eko-tek kentler (eco-tec cities), yeşil kentler (green cities), sağlıklı kentler (healthy cities) ve yaşanabilir kentler (livable cities) gibi çeşitli uygulamalar ve yaklaşımlar da geliştirilmektedir (Van Kamp et al., 2003).

$\mathrm{Bu}$ yaklaşımlar, sürdürülebilirlikle birlikte ortaya çıkan yeni kavramları, çözümleri ve uygulamaları içeren farklı isimlere sahip olmalarına rağmen, temelde kentlerin büyümesi ve gelişmesini kontrol altına almayı ve daha sağlıklı, doğa ile daha uyumlu ve yaşam kalitesi yüksek kentsel çevreler üretmeyi hedeflemektedir. Küresel sürdürülebilirliğin sağlanması, kentlerin ekolojik, sosyal kültürel, ekonomik yönden sürdürülebilirliğini zorunlu hale getirdiği için, yerel ölçekte hayata geçirilen uygulamaların, küresel ölçekte etkili olması beklenen çözümleri bulunmaktadır (Aklanoğlu, 2009).

Bu çerçevede, bu yaklaşımların yereldeki çözüm arayışları mahalle/ komşuluk gelişimine odaklanmaktadır. Sharifi'ye göre (2016), sürdürülebilirlik ve sürdürülebilir mahalle/komşuluk gelişimi nispeten yeni kavramlar iken, bir disiplin ve meslek olarak mahalle planlaması 20. yüzyılın başlarından beri uygulanmaktadır. Bu nedenle, sürdürülebilir kentsel alanlar ve mahalle geliştirmeye yönelik yeni yaklaşımların, sanayi toplumunun sorunlarını çözmek için geliştirilen Howard'ın Bahçe Şehir ütopyasına kadar uzandığı ve 20. yüzyılın başlarından itibaren yaşanabilir ve çevre dostu mahalleler geliştirmeye çalışan kentsel planlama ve tasarım eğilimlerinin devamı niteliğinde olduğu söylenebilir.

Bu nedenle makalenin bu bölümünde, Bahçe Şehir ve Komşuluk Birimi yaklaşımları ilk ekolojik yaklaşımlar olarak incelenmiştir. Daha sonra, YeniGeleneksel Planlama, Akıllı Büyüme ve Eko-şehircilik gibi sürdürülebilir 
kentleşme akımlarına değinilmiştir. Diğer yaklaşımlar, kökeni ve ilkelerinin temelinde, bu akımların alt kümeleri olarak değerlendirilmiştir.

\section{Bahçe Şehir Modeli}

Ebenezer Howard (1898) tarafından geliştirilen Bahçe Şehir modeli ortaya çıktığı dönem itibariyle, karbon ayak izi ve düşük karbonlu gelişme, iklim değişikliği ve teknolojilerin bir arada kullanılmasını dikkate almasa da (Sharifi, 2016), bugün hala gündemde olan ve uydu-kentleşme olarak söz edilen yaklaşıma temel oluşturmuştur. Bahçe Şehir, Londra'nın kalabalığından uzakta kır ve kenti birleştiren ve olumlu yönlerini alan bir modeldir. Çevredeki yeşil alanlara yakınlığı sağlamak için orta yoğunluklu ve sınırlı büyüklükteki yerleşim alanlarını ve bunlarla entegre olan yeşil alanları içermektedir. Bahçe şehir modelinde kentin plansız gelişimini kontrol etmek ve böylece komşu yerleşimlerle birleşmesini önlemek için önerilen kenti çepeçevre saran yeşil halka, günümüzdeki yeşil kuşak kavramına temel oluşturmuştur. Ana şehir ve etrafındaki uydu şehirlerin demiryolu hatlarıyla birbirine bağlanması bölgesel bir sistem olarak kurgulanmıştır (Gaffron, Huismans, Skala, 2005). Yeşil kuşaklı bu uydu-kent modeli Londra çeperinde iki kentte uygulanmıştır (Ercoşkun, 2018).

\section{Mahalle/Komşuluk Birimi}

Bahçe şehir hareketiyle yakından ilgili olan Clarence Perry, Henry Wright ve Clarence Stein tarafından metropoliten kentlerin en küçük yaşam çevresi birimi olarak tasarlanan Mahalle/Komşuluk Birimi önerisi, kalabalık şehirlerin olumsuzluklarını azaltmak amacıyla, düşük yoğunluğa sahip yaşam alanlarını içermektedir (Sharifi, 2016). Otomobillerin ve yayaların birbirinden ayrıldığı, trafiğe kapalı alanların ve yaya ağlarının bulunduğu mahalle birimlerinde, yayalar güvence altına alınarak kesintisiz bir ulaşım sistemi tasarlanmıştır. Açık alanda yer alan kamu tesisleri ve ticaret birimlerini içeren mahallelerde, kent sakinlerinin kendi evlerine ve ticaret alanlarına ulaşması için (ana arterleri geçmeden) 400 metreden fazla yürüyüş yapmasına izin verilmemektedir. Bu plan ayn zamanda, sosyal ve fiziksel alanlarda komşuluk etkileşimlerini geliştirmeyi, yüz yüze temaslar için fırsatlar sağlamayı ve yaşayanların aralarındaki topluluk duygusunu geliştirmeyi hedeflemiştir (Jabereen, 2006). 


\section{Yeni-Geleneksel Planlama ve Yeni Şehircilik}

Yeni-geleneksel planlama (neo-traditionalism) yaklaşımı, 20. yüzyılın ikinci yarısında Amerikan şehirlerinde ortaya çıan uydu-kentleşme, kentsel yayılma, şehir içi mahallelerde eskime ve yoksulluk, suç, sosyal ayrışma gibi olguların artması ile trafik sıkışıklığı ve kirlilik gibi sorunları çözme amacıyla 1980'lerde post-modern bir şehircilik hareketi olarak ortaya çıkmıştır. Uydukentleşme öncesi tanımlanabilir sınırları olan geleneksel Amerikan mahallelerini taklit etmeye çalışan Yeni Şehircilik (New Urbanism) ilkeleri birçok mahalleyi tasarlamak için kullanılmıştır. Bu mahalleler, çevreyi planlara ve tasarıma dahil etmek, estetik nitelikleri ve yoğunluğu arttırmak, karma-kullanım sağlamak, geleneksel mahalle yaşamını canlandırmak, yürüyüşü teşvik etmek ve taşıtların yerine yürüyüş ve bisikleti koymak gibi konularda belirli başarılar yakalamışlardır. Ancak, yoğunluk, yürünebilirlik ve kent içi ulaşımda çevre bilincinin ve toplulukların sürdürülebilirliğinin arttırılmasında etkili olamadıkları yönünde eleştiriler de bulunmaktadır (Jabareen, 2006).

\section{Akıllı Büyüme}

Akıllı büyüme (smart growth) yaklaşımı, Amerika'da 1996 yılından itibaren kentsel büyümenin kontrolü kapsamında planlama gündeminde yer almaya başlamıştır. Sürdürülebilirliğin kentsel büyümeye karşı duruşu yerine, duyarlı büyüme konusunda uzlaşmayı savunmaktadır. Kentsel saçaklanmaya karşı ortaya çıkan bu akımın temel özelliklerini, daha düşük çevresel etkiye sebep olacak şekilde yüksek yoğunluklu karma alan kullanımı ve yoğun yapı tasarımı oluşturmaktadır. Diğer bir deyişle, kentsel alanın enerji ve çevresel potansiyeller açısından etkin kullanımını hedefleyen ve kentsel arazi kullanımında karma kullanımı öngören "kompakt kent formu" ile, otomobile dayalı kentsel yayılmanın karşısında durmaktadır (Să̆, 2011).

\section{Eko-Şehircilik}

Üçüncü bölümde ayrıntılı olarak incelenecek olan Eko-şehircilik, 20'nci yüzyılın sonunda çevre ve sürdürülebilirlik kaygılarının artmasıyla ortaya çıkmıştır. Kökeni, 1980'lerin başında Richard Register tarafından kentin biyolojik yöneliminde ekolojik taşıma kapasitesinin dikkate alındığı ekolojik şehirler önerisine dayanmaktadır. Ekolojik kentsel girişimler, kentsel metabolizma ve sürdürülebilirlik kavramlarıyla da ilişkili olan Eko-şehircilik, dünya çapında yayılmış olmakla birlikte çıkış nedenini iklim değişikliği oluşturmaktadır. Kaynakların akıllı ve verimli kullanımını sağlayarak karbon ayak izi ve düşük karbonlu gelişmeye ve teknolojilerin bir arada kullanılmasına 
odaklanmaktadır. Kentsel alanların tasarımında, orta-yüksek yoğunlukların ve bağlantıların güçlü olduğu farklı ulaşım biçimlerinin kullanılmasını önermektedir. Akıllı şebeke, su arıtma sistemleri, katı atık yönetim sistemleri, güneş teknolojisi, gerçek zamanlı ulaşım bilgileri gibi evrensel teknolojilere yer vermektedir. Ulusal ve uluslararası düzeyde katılım ile performans değerlendirme araçlarının geliştirilmesiyle ilgilenmektedir (Sharifi, 2016).

Çevresel sürdürülebilir politikaların yansıması olarak ortaya çıkan bu yaklaşımların her biri bir öncekine alternatif olacak şekilde günümüze kadar gelişmeye devam etmişlerdir. Bu yaklaşımların en önemli ortak noktası mevcut yapılaşmanın iyileştirilmesi ve kent çeperlerindeki yeni yerleşimlerin sürdürülebilir gelişmesini sağlama çabasıdır. Önerdikleri yerleşim özelliklerine bakıldığında, yoğunluk, alan büyüklüğü gibi fiziksel özellikler açısından farklılıklar göstermektedirler. Buna rağmen, ortak kaygının hızlı kentleşme ile hizmet ve ürünlerde artan talep ve tüketim baskısının çevreye verdiği zararın azaltılması yönünde kentlerin mümkün olduğunca sürdürülebilirliğinin sağlanması olduğu görülmektedir (Aydın ve Tezer, 2011).

Sürdürülebilir kentleşmeye ilişkin bu yaklaşımlar, bölgesel, metropoliten, kentsel, topluluk ve bina gibi farklı ölçeklerde ele alınmış olmalarına rağmen, bunları karşılaştırmak için kullanılan ve üzerinde uzlaşılmış kavramsal bir çerçeve bulunmamaktadır. Diğer yandan, kentsel biçim açısından incelendiğinde önerdikleri ortak ilkelerin "derişiklik (kompaktlık), sürdürülebilir ulaşım, yoğunluk, çeşitlilik, karma arazi kullanımı, pasif enerji kullanımı ve yeşil tasarım" gibi benzerlikler taşıdığı görülmektedir (Jabareen, 2006). Bu ilkeler aşağıda açıklanmıştır:

- Derişiklik: Derişiklik, gelecekteki kentsel gelişimin mevcut kentsel yapılara bitişik olmasını ve bağlanabilirliğini sağladığı, mevcut yayılmanın azaltılmasından ziyade kentin daha fazla yayılmasını engellediği ve enerji, su, malzeme, ürün ve insan taşımacılığını en aza indirgediği için, daha sürdürülebilir bir kentsel biçim olarak kabul edilmektedir.

- Sürdürülebilir Ulaşım: Ulaşım, kentsel biçimle ilgili çevresel tartı̧̧maların en büyük sorunudur. Kentlerin biçimi, büyük ölçüde gelişimlerinin farklı aşamalarında baskın olan ulaşım teknolojilerini yansıtmaktadır. Sürdürülebilir kentsel gelişim politikaları kent içi seyahat ve hareket ihtiyacını azaltmak, enerji verimli ve çevre dostu taşımacılık biçimleri oluşturmak için önlemler içermeli ve arazi kullanım planlamasını bu anlamda ele almalıdır.

- Yoğunluk: Yoğunluk ve konut tipi, enerji tüketimindeki farkl1lıklar nedeniyle sürdürülebilirliği etkiler. Yüksek yoğunluklu ve entegre arazi 
kullanımı sadece kaynakları korumakla kalmaz aynı zamanda sosyal etkileşimi de teşvik eden bir derişiklik sağlar. Yoğunluk arttıkça bireysel araç kullanımı azalarak kişi başına düşen yakıt miktarı azalır. Yoğunluk, bölgesel (büyükşehir) ve yerel ölçekte kentsel yapı ve kalkınma modelinin temel ve muhtemelen en yaygın kullanılan uluslararası ölçüsüdür.

- Çeşitlilik: Jane Jacobs tarafından 1961'de popüler hale getirilen çeşitlilik kavramı, daha sonra yeni şehircilik, akıllı büyüme ve sürdürülebilir kalkınma gibi birçok planlama yaklaşımında benimsenmiştir. Yoğun ve çeşitlendirilmiş kentlerde insanlar canlı ve hareketli yaşayan yerlere özel araçlarıyla gelmiş olsalar bile araç kullanmayı değil yürümeyi tercih etmektedirler (Jabareen, 2006). Yürümeyi veya bisiklet kullanımını teşvik eden planlamadaki çeşitlilik, canlı ortamların oluşmasına katkı sağladığından insanlar arasındaki sosyal etkileşimleri de arttırmaktadır.

- Karma Arazi Kullanımı: Kentsel alan kullanımlarının karma olarak planlanması yürüme ve bisiklet kullanım mesafelerini azaltarak kullanımlarını teşvik etmekte, seyahat edilen araç kilometrelerini düşürmekte, hava kalitesini iyileştirmekte ve şehir estetiğini geliştirmektedir. Arazi kullanımlarının homojenleşmesi ile işyeri konut mesafeleri artmakta, bireysel otomobil kullanımına ağırlık verilmekte ve çevreye olumsuz etkilerinin azımsanmayacak kadar fazla olduğu kanıtlanmış kentsel yayılmaya neden olduğu görülmektedir. Konutların (genellikle düşük yoğunluklu yayılma durumunda tek aileli evler) ticari işletmelerden uzak mesafelere yerleştirilmesi, yürümeyi engellerken, araç bağımlılığını arttırmaktadır (Nedovic-Budic ve ark., 2016).

- Pasif Enerji Kullanımı: Sürdürülebilir kentsel biçimler enerji kullanımının azaltılmasında önemli rol oynamıştır. Yapılaşmış kentsel alanlar, açık alanlarla karşılaştırıldığında, birim alan başına daha geniş yüzeylere sahiptir. Bu nedenle, özellikle kışın, düz ve açık bir araziden ziyade, yerleşik bir kentsel alanın yayılan güneş ışınlarını daha fazla toplama potansiyeli bulunmaktadır. Geleneksel enerji kaynaklarıyla binaların 1sınması veya soğutulması ihtiyacını en aza indirgemek için yapılan tasarım, yerleştirme, yönlendirme, yerleşim ve peyzaj düzenlemeleri, güneş enerjisi kazanımı ve mikro iklim koşullarının optimum düzeyde kullanımı sağlamaktadır (Jabareen, 2006).

- Yeşil Tasarım: Kentsel yeşil alanlar sürdürülebilir kent biçiminin önemli tasarım kavramları arasında yer alır. Tasarımcılar doğayı, kent kullanıc1larının yaşamlarına dahil etmenin yolunu açık peyzaj alanlarının çeşitliliği ile aramaktadır (Jabareen, 2006). Ekolojik ve rekreasyonel amaçlarla 
planlanmış ve yürüme izleriyle desteklenmiş yeşil kuşakla bütünleşen kentsel açık alanlar ve doğal koridorlar, erişilebilirliği artırmada önemli etkiye sahiptir (Kurtaslan ve Önder, 2009)

\section{Ekolojik Kentleşme, Planlama ve Tasarım}

Ekoloji kavramı, ilk kez 1866 yılında Alman biyoloğu Ernst Haeckel tarafından Yunanca yaşanılan yer, yurt anlamına gelen "oikos" ile bilim ya da söylem anlamlarına gelen "logia" sözcüklerinden türetilmiştir. Ekoloji, tüketilen enerji kaynaklarının üretimi ve atıkların yok edilmesi için gereken kara ve su alanlarının büyüklüğünü kapsar. Belirli bir toplumda yaşayan insanların üretimi ve tüketimi sonucunda oluşan bu etkinin tümü, o toplumun dünya üzerindeki ekolojik ayak izini ifade eder. Sağlıklı ve sürdürülebilir yaşam çevreleri için ekolojik ayak izinin tüm dünyada küçültülmesi gerekmektedir (Çalışkan Samur, 2010).

Son yıllarda insanların çevreye karşı davranış ve tutumlarının değişerek farkındalıklarının artmasının nedeni, çevre sorunlarının yarattığı olumsuz etkilerin tüm dünyada görülmesi ve hissedilmesidir. Ekolojik dengenin bozulması ile ilgili farkındalığın artmasıyla eş zamanlı olarak, yaşanabilirlik seviyesi, kentlerin taşıma kapasitesi ve yaşam kalitesi gibi konular üzerinde neler yapılabileceği de araştırılmaya başlanmıştır. Sınırlı olan doğal kaynakların gelecekte tükeneceği göz önüne alınarak doğal kaynakların geri dönüşümü konusunda bazı yaklaşımlar geliştirilmiştir (Aklanoğlu, 2009).

Ekolojik yaklaşımın temel nitelikleri şöyle ifade edilebilir: Ekolojik yaklaşım, bütün bir sistemi kapsamaktadır. Bu yaklaşım, öğeler arasındaki iç ilişkilere odaklandığı için, ekosistemin doğal unsurları olan hava, su, toprak, canlı organizmalar gibi bileşenler arasındaki ilişkiler önem taşımaktadır. Aynı zamanda çevrenin doğal, fiziksel, ekonomik, toplumsal ve kültürel çevreleri kapsayan geniş bir tanımını kullanmaktadır. Ekosistemin dinamik yapısını ve doğasını kabul ederek, insan eylemlerine sınırlamalar getirilmesini önermesi nedeniyle taşıma kapasitesi, esneklik ve sürdürülebilirlik kavramlarını kapsamaktadır. Yönetsel sınırlardan çok, doğal coğrafi birimlere dayanır. Ekolojik yaklaşım temelde insanlardan başka türlerin ve var olan kuşaklar ile birlikte gelecek kuşakların önemini vurgulamaktadır (Özcan 2007).

Ekolojik planlama, sürdürülebilir bir yaşam için toplumların gereksinimlerini doğal ekosistemlerin dengesini bozmadan karşılamayı ilke edinen planlama yaklaşımıdır. Ekolojik planlama kavramı, kentsel gelişmeyi ekonomik, sosyal, toplumsal, çevresel ve fiziki boyutları ile ele almakta ve bunların 
karşılıklı etkileşimlerini içermektedir. Bu kapsamda sosyal, ekonomik ve ekolojik sistemin bütünleştirilmesi ile sürdürülebilir kentler oluşturulabilmektedir. Sürdürülebilirliğin çevresel amaçlarını yerine getirmek için, kentsel planlama yerel iklimi, ekosistemleri, materyalleri, enerji, su ve kaynak akışlarını yansıtmalıdır (TBB, 2017a). Bu yaklaşım çerçevesinde kentlerde açık ve yeşil alan sistemleri, özellikle mekânsal planlama düzeyinde önemli girdiler olarak ortaya çıkmaktadırlar.

Ekolojik planlama, aynı zamanda kent planlamasının bütünü içinde değerlendirilmelidir. "Kentsel gelişmenin sürdürülebilirliği için, kentsel etkinliklerin çevre bilimsel ilkelere uygun biçimde gerçekleştirilmesi" düşüncesinin iki önemli boyutu vardır: Birinci boyut kentsel alanların (veya arazilerin) rant sağlamak amacıyla parçalanmasının önüne geçmekle ilgilidir. Böylece doğal ekolojik alanların, tarım arazilerinin, yeşil alanların, tarihsel ve kültürel değerlerin rant üretmek amacına hizmet eden uygulamalardan korunması sağlanmış olacaktır. İkinci boyut ise, kentleşme sürecinin öteki ucunda yer alan kırsal alandaki dar gelirli öbeklerin koşullarının iyileştirilmesi ve kentleşme sürecine dâhil edilmesi ile ilgilidir (Özcan, 2007).

Özcan'a (2007) göre sürdürülebilir bir ekolojik planlama yaklaşımı, sürdürülebilir kentsel gelişmeyi yönlendirmesi açısından önemli olduğu gibi, yapılı çevrenin değişmesi ve gelişmesi sürecinde çevreye ve doğaya zarar vermeyecek ölçüde bütüncül olarak korunmasına önayak olmaktadır. Böylece, geleceğe taşınan kaynaklarla yaşam kalitesi daha iyi çevrelerin oluşturulması ve aktarılması mümkün olabilmektedir.

Sürdürülebilir ve ekolojik kentlerin nasıl olması gerektiğine dair farklı görüşler olmasına rağmen, dünyadaki uygulamalar incelendiğinde iki tür ekolojik kentleşme yaklaşımı bulunduğu söylenebilir. Bunlardan ilki mevcut kentsel çevrelerin ekolojik ilkeler doğrultusunda dönüşümüyle ilgilenirken, diğeri eko-kentlerin kurulmasını hedeflemektedir. Her iki uygulama da temeldeki hedefi aynı olan, ekolojik kent olma çabası göstermekte ve atık yönetimi, yenilenebilir enerji, yeni nesil teknoloji kullanımı, sürdürülebilir ulaşım (yaya öncelik ve toplu taşıma odaklı), yeşil alan miktarının arttırılması gibi değişimlere odaklanmaktadır.

Mevcut kentsel alanlarda ekoloji dostu yaklaşımlar arasında yer alan örneklere kısaca değinildiğinde, Kopenhag (Danimarka), dünyadaki en çevre dostu şehirler arasında ilk sırada yer almaktadır. Şehir sakinlerine yüksek yaşam kalitesi sunmak ve çevre dostu bir kent olmak amaciyla hedeflerini belirleyen kentte, gelişmiş bisiklet ulaşım ağları planlanmış, bireysel araç kullanımı \%29'a düşürülmüş ve 2025 yılına kadar karbondioksit salımının sıfıra 
düşürülmesi hedeflenmiştir. Bunun yanı sıra gıda sektöründe organik üretim ve tüketimi destekleyen kentte çevre dostu bir yaşam tarzını sürdürülebilir kılmak adına pek çok uygulama hayata geçirilmiştir.

Benzer biçimde, Amsterdam (Hollanda) kentinde, başlıca ulaşım aracı bisiklet olmakla birlikte, kent sakinleri konut çatılarına güneş panelleri kurarak yapıların çevre dostu olmasına özen göstermekte, yerel çiftçi pazarların kullanarak yerel ekonomiye destek vermekte ya da kendi besinlerini kendileri üretmeyi tercih etmektedirler. Stockholm (İsveç) kenti ise, yeşil toplumu teşvik etmek amaciyla fosil yakıtlara son vermeyi hedeflemiş olup, kanalizasyon atıklarından bio-yakıt elde etmek ve kentteki stadyumda oluşan ısı israfına yönelik geri kazanılan ısıyı konutlarda kullanmayı hedefleyerek ekolojik kent olma çabasını sürdürmektedir.

San Francisco (Kalifornia) kenti ve Portland (Oregon) kenti plastik poşet ve su şişesi kullanımını yasaklamış, atık geri kazanımı ve yenilenebilir enerji kullanımı üzerine yoğunlaşmıştır. Güneş ve rüzgar enerjisini kullanan, Cape Town (Güney Afrika) ve Helsinki (Finlandiya)enerji üretimi ve atık yönetimini önemseyerek ekolojik kent olma çabasını sürdüren diğer kentler arasinda yer almaktadır.

Bir sonraki bölümde, kentlerin çevreye verdiği zararın en aza indirgenmesini hedefleyen eko-kentler incelenmektedir.

\section{Eko-Kentler ve Temel İlkeleri}

Nüfus artışının ve kentsel dinamiklerin doğal çevre üzerindeki tahrip edici etkilerinin günlük yaşam içerisinde hissedilebilir duruma gelmesi, doğanın korunması hakkındaki farkındalığın planlara yansıtıldığı, kaynakların akılcı kullanımını ve insanların sağlıklı, huzurlu ve güvenli bir yaşam ortamında hayatlarını sürdürmelerini esas alan ekolojik planlama ile oluşmuş eko-kentlere ihtiyaç duyulduğunun bir göstergesidir (Iş̧ldar, 2012).

Eko-kent kavramı, kentlerin sürdürülebilirliğine yönelik arayış ve çabaların sonucu ortaya çıkmıştır. Eko-kent, insan, kent ve çevrenin birbirleri ile ilişki ve etkileşim içerisinde ele alındığı bir kent tasarım ve uygulama yaklaşımıdır. Ekolojik kent gelişimi en saf haliyle konutlar, fabrikalar, ofisler, altyapı tesisleri ve kaynak tüketimini azaltan açı alanlar yaratma tutkusu ile kaynakları mümkün olan en yüksek oranda yeniden kullanan, atıkları geri dönüştüren ve kalan atıkları değerlendiren bir sistemi tarif etmektedir. Kısacası ekolojik kent; hâkim tüketici toplumlarla ve giderek daha zenginleşecek 
şehirlerin gelecekteki sakinlerinin beklentileri ile dramatik bir biçimde zıt bir kentsel gelişim biçimi gerektirmektedir (Lee ve Yigitcanlar, 2014).

Genel olarak eko-kent güçlü bir kimliğe sahip olmalı, böyle bir yerleşmede hayat doğa ile iç içe, yeşillikler içinde, yaşanılır ve ayrıcalıklı bir yerleşme olmalıdır. Güvenli ve rahat yürüyüş yollarıyla, caddeleri, açık alanları, dükkân ve kafeleri ile sokak yaşamına önem veren ve sosyal yaşamı destekleyen özelliklere sahip olmalıdır (TBB, 2017a).

Gül ve Polat'ın (2002) çalışmasında vurgulanan bütüncül ekolojik kent yaklaşımında, doğal ve yeşil alanların yoğunluğunun artırılması, temiz enerji kullanımı, çevre dostu teknolojinin kullanımı, ekolojik tabanlı kentsel, mekânsal ve mimari yapıların planlama ve tasarımı, ekolojik ve çevre koruma konusunda eğitim (bilgilendirme ve bilinçlendirme) faaliyetleri, ekolojik ulaşım çözümleri, denetleme ve izleme, tasarrufun yaygınlaştırılması, çevre dostu ve uyumlu malzemelerin kullanımı gibi çok yönlü bileşenlerle eyleme dönüşüm gerektiği üzerinde durulmaktadır.

Aydın'a (2010) göre, eko-kentlerin temel hedefi, üretim tarzın, tüketim alışkanlıklarını ve karar mekanizmalarını değiştirerek, yerel ekosistemlerin taşıma kapasitesini sürdürülebilir açıdan geliştirmektir.

Gaffron P, Huismans G. Skala F.'in (2005) çalışmasında eko-kentler planlanırken, hedeflerin belirlenmesi ve bu hedefler için birden fazla sektöre odaklanıp desteklenmesi gerekliliğinden bahseder. Bu hedeflerin birçoğu, kentsel planlama özniteliğini en üst düzeye çıarmak ya da en aza indirgemek için formüle edilmelidir. Bu bağlamda, bir şeyi en aza indirmek (örneğin arazi kullanımı veya enerji tüketimi), onu \% 0'a düşürmek anlamına gelmez, ancak diğer ilgili hedefleri göz önünde bulunduran optimum bir asgari seviyeye ulaşmak anlamına gelir. Benzer şekilde, bir şeyi en üst düzeye çıkarmak (örneğin, doğal içeriğe saygıyı en üst düzeye çıkarmak), maksimum seviyeye erişmek için optimum bir aralığı elde etmek anlamına gelir.

Gaffron P, Huismans G. Skala F.'in (2005) diğer bir çalışmasında Eko-Kentin hedefleri şu şekilde ifade edilmektedir:

- Arazi talebini en aza indirgemek (özellikle yeşil alanlar için)

- Birincil malzeme ve birincil enerji tüketimini en aza indirgemek

- Belediye ve bölgesel malzeme akışlarıyla etkileşimi optimize etmek

- Doğal çevrenin bozulmasını en aza indirgemek

- Doğal içeriğe saygı duymak

- Taşıma talebini en aza indirgemek

- Temel ihtiyaçları karşılayan yapılar oluşturmak

- İnsan sağlığının bozulmasına neden olanları en aza indirgemek 
- Zihinsel refahı ve topluluk duygusunu en üst düzeye çıarmak

- Antropojenik içeriğe saygıyı en üst düzeye çıarmak

- İyi yönetim için bir çerçeve oluşturmak

- Sürdürülebilir kalkınma bilincini en üst düzeye çıkarmak

- Çeşitlendirilmiş, krize dayanıklı ve yenilikçi bir yerel ekonomi gerçekleştirmek

- Toplam yaşam döngüsü maliyetlerini en aza indirgemek (üretkenliği en üst düzeye çkarmak)

Hedeflerin çoğu birbirine bağlıdır. Ya aynı doğrultuda, az çok işaret ederler ya da açıkça görünüşte zıt iki hedef için bir çözüme ihtiyaç duyarlar (örneğin, ulaşım talebini en aza indirmeye karşı, örneğin mobilite için temel ihtiyaçları karşılama). Bu hedeflerin en iyi şekilde yerine getirilmesi için, yerel koşullar da dikkate alınmalı (iklim, kültür, çevre sorunları, vb.) ve böylece her bir geliştirme görevi veya projesi için planlama çözümleri ayrı ayrı belirlenmelidir.

1990 yılında ilk kez Kaliforniya' da düzenlenen eko-kent konferansı ile bu konu hakkında hızlı bir gelişim sağlanmıştır. Her sene dünyanın farklı bir şehrinde yapılmaya devam eden bu konferanslardan biri, 2009 yılında İstanbul'da yapılmıştır. Bu toplantılar sonucu ortaya çıkan rapora göre eko-kent ilkeleri :

- Alan kullanımı önceliklerini, ulaşım altyapısının ve aktarma noktalarının bulunduğu noktalara yakın olacak şekilde, derişiklik ve çeşitlilik içeren, yeşil, güvenli, cazip ve özellikle karma kullanımlı alanlar oluşturmak için tekrar gözden geçirmek;

- Yaya ve bisiklet ulaşımı ile toplu taşımayı destekleyen ve ulaşıma yakınlık üzerinde odaklanan ulaşım öncelikleri oluşturmak; özellikle koylar, kıyı alanları ve sulak alanlar gibi zarar görmüş kentsel ve doğal çevreleri rehabilite etmek;

- Nezih, güvenli, kullanışlı ve ekonomik, kültürel açıdan karma kullanımlı konut alanları yaratmak; toplumdan dışlanan insanlar, kadınlar ve engelliler için sosyal adaleti sağlamak ve öncelikleri kurmak;

- Yerel tarımi, kentsel yeşillendirme projelerini ve kamu bahçelerini desteklemek; geri dönüşümü, yenilikçi uygun teknoloji kullanımını teşvik etmek; kaynakları korurken kirliliği ve tehlikeli atıkları azaltmak; 
- Kirlilik, atık ve tehlikeli maddelerin kullanımını engellemek için ekolojik ekonomik aktiviteleri desteklemek üzere yeni iş alanları oluşturmak;

- Gönüllük esaslı basit, sade yaşam tarzını teşvik etmek ve artan tüketim alışkanlıklarının önüne geçmek; yerel ve bölgesel doğal çevre hakkında farkındalığı artırmak için aktivistler ve eğitim projeleri ile toplumda ekolojik sürdürülebilirlik konuları hakkında bilinç oluşturmak şeklinde sıralanmıştır. (Aydın,2010).

Türk - İsveç Yerel Yönetimler Ortaklığı Programı (TUSELOG) raporunda, eko-kentin temel özelliklerini şöyle özetlenmiştir:

- Kentsel teknoloji ile doğanın korunması arasında bir işlevsel bütünlük sağlar.

- Doğal kaynakları en etkili şekilde kullanan yeni sistem çözümlerini teşvik eder.

- Etkili ve demokratik süreçleri gerçekleştirmek için en iyi uygulamalardan yararlanir.

- Eko-kent yaklaşımında sosyal ve ekonomik faktörlere, en az ekolojik ve teknik faktörler kadar önem verilir. Çünkü nihai amaç; herkese, doğa ile uyum içinde; sağlıklı, güvenli, huzurlu ve yüksek kalitede bir yaşam sağlamaktır.

- Eko-kent yerleşim olarak, metropol ile bağlantı içinde ulaşılabilir olmalıdır. Kentsel gelişme, metropole eklemlenerek, ana ulaşım akslarına erişilebilir olmalıdır.

- Eko-kentte yaşayanlar, kentli bir topluluk yaşamını kurabilmek için dengeli bir nüfus yapısına sahip olmalıdır. Değişik gelir gruplarına hitap etmeli, binalar sosyal alt yapı ile ilişki içinde olmalıdır. Kent halkı, ortak yaşam alanlarını daha çok kullanabilmelidir.

- Eko-kent enerji, arazi kullanımı, su ve atık su kullanımı açılarından doğal kaynakları koruma konusunda net hedeflere ve programlara sahip olmalıdır.

- Eko-kent sivil bir liderlikle, yerel yönetimlerin desteğini alarak, uzun vadeli hedefler etrafında kuruluşlar arası işbirliğini gerçekleştirme yaklaşımında olmalıdır.

- Çok yönlü kültürel ve ekonomik gelişmeyi hedefleyen işlevlerin yer aldığı eko-kent, cazip bir kültür, sanat ve iş merkezi olmalıdır.

- Arazi, doğal ve yapılanmış çevrenin işlevsel entegrasyonunu sağlayacak şekilde kullanılmalıdır (TBB, 2017a) 
Eko-kentler günümüzde pek çok ülke tarafından dünyanın çeşitli bölgelerinde uygulama örnekleriyle çoğalmaktadır. Bunlar arasında; KazakistanAstana Eko-kenti, Almanya-Freiburg, Avustralya-Moreland Eko-kenti, ÇinSingapur, Çin-Tianjin Eko-kenti, Danimarka-Kalundborg Endüstri Parkı, Almanya-Vauban, Hindistan-Karakal Eko-kenti, Hong Kong-Hung Shui Kiu Eko-kenti, Cleveland-ABD, Curitiba-Brezilya, Toronto-Kanada, Vaxjo-İsveç, Sydney-Avustralya, Kampala-Uganda, Puerto Princesa-Filipinler, Reykjavikİzlanda, Masdar Eko-kenti-Abu Dabi eko-kent örnekleri verilebilir.

Dünyanın ilk tamamen sürdürülebilir topluluklarından biri olarak planlanan (2006) Masdar Kentinin (Birleşik Arap Emirlikleri) planlama yaklaşımında yedi temel ilke ön plana çıkmaktadır: verimli enerjinin oryantasyonu, yerleşim yerlerinin uyumu, az katı binalar, yüksek yoğunluklu binalar, canlı kamusal alan, yaya dostu kentsel mekân Masdar kentinde geleneksel planlama ilkeleri sıfır karbon, sıfır atık yaratma hedefi çerçevesinde harmanlanmış ve yenilebilir enerji kaynaklarının kullanımı hedeflenmektedir. Sharifi'ye göre (2016), Masdar kentinin başlıca odaklandığı nokta sosyal boyutlar pahasına ekonomik sürdürülebilirlik olmuştur. Kapsayıcılık ve bağlılık gibi konular iyi düşünülmemiş olup ekonomik kriz durumunda projenin çöküşüyle ilgili endişeleri de beraberinde getirmektedir.

Bir diğer dünya örneği ise, 2007 yılında temelleri atılan sosyal ahenge sahip, çevre dostu, kaynak tasarruflu ve uyumlu Tianjin (Çin) Eko-Kenti'dir. Diğer dünya Eko-kentlerinden farklı olarak tasarımın birebir aynısının diğer Çin şehirlerinde tekrarlanabilir bir model olarak tasarlanmasıdır. Proje tasarımcıları tarafından projede, üç uyum ve üç kabiliyet teması belirlenmiştir. Üç uyum; diğer insanlarla uyum, ekonomik aktivitelerle uyum ve çevreyle uyumdur. Kabiliyetler ise; pratik ve kullanılabilir teknolojiler, Çin ve diğer ülkeler için de model oluşturabilecek ve uygulanabilecek bir şehir tasarımı, projenin farklı ölçeklerde geliştirilebilir ve adapte edilebilir olmasıdır (Çetinkaya, 2013).

Astana(Kazakistan) Ekokenti'nin özelliği ise dengeli gelişen kentsel fonksiyonlarla simbiyotik bir kent oluşturulmaya çalışılması için ekolojik bir master planına sahip olmasıdır. Uluslararası ödüle sahip Ekolojik master planı 1998'de yapılmış olup planın anahtar kelimeleri metabolizma, geri kazanım, ekoloji ve simbiyozdur. Simbiyoz; farklı canlıların birlikte yaşaması olarak ifade edilebilir. Örnekle açılamak gerekirse master planı hazırlayan tasarımcılar, gri suları var olan balık havuzlarına bağlayarak 700 hektarlık bir iç deniz 
oluşturarak yeşil bitki örtüsü yardımıyla eko koridorlar yaratmayı planlamıştır. Bu eko koridorlar aracılı̆̆ıyla yalıtılmış sistemlerin birbirine bağlanması simbio kent kavramında çok önemli yer tutmuştur.

Detaylandırılan ve incelenen diğer örneklere bakıldığında temeldeki hedefleri aynı olan eko-kentlerin her birinin farklı konulara odaklandığı görülmektedir. Böylece ön plana çıardıkları farklı olgularda ilerleme sağlayarak ekolojik çevreye katkı sağlamanın yanı sıra, eko-şehirciliğin mahalle sınırları ötesinde kentsel bir bütün olarak ele alan küresel ölçekte örnekler sunmaktadırlar. Örneğin, Masdar düşük karbonlu kalkınmayı teşvik etmeye çalışırken, Astana dengeli gelişen kentsel fonksiyonlarla simbiyotik bir kenti, Tianjin ise sosyal olarak uyumlu, çevre dostu ve kaynak verimli kullanımı teşvik etmektedir. Ancak, sürdürülebilir topluluklar elde etmek için farklı ölçekler ve sektörler arasında uyumlu ve koordine edici çabalara ihtiyaç vardır (Sharifi, 2016).

Türkiye, günümüzde ekolojik planlama yaklaşımlarını, kent formunu yönlendiren planlama politikalarına yavaş yavaş entegre etmeye başlamıştır. Bursa-Nilüfer Eko-kent Projesi, Eskişehir-Sürdürülebilirlik Performanslı Kentsel Dönüşüm (Süper Kent Sistemi) Projesi ve Konya-Bizim Şehir Projesi, Gaziantep olmak üzere ülkemizde planlama ve tasarım ölçeğinde çalışılmış ancak henüz uygulamaya geçmemiş dört farklı çalışma bulunmaktadır.

\section{Bursa Nilüfer Eko-Kenti}

Bursa İli Nilüfer İlçesi içinde 2.150 hektar alana sahip planlama alanında, doğal çevre ile daha uyumlu ve işlevsel anlamda bütüncül yeni bir yerleşim önerilmiştir. Kur-kent gelişme birlikteliğini dikkate alan projede, kentsel projelerin uygulanmasında insan ve çevre sağlı̆̆ına öncelik verilmesi amaçlanmiştır. Önerilen eko-kentte, çevre ile topografyaya uyum ve doğal eşikler konusunda hassasiyetin yanı sıra yenilenebilir enerji sistemlerinin kullanıldığı, karbon salınımını en aza indirgemeyi amaçlayan ekolojik hassasiyetlerin de yüksek olduğu görülmektedir. Yaşama ve çalışma alanlarının birlikteliği ile refahı artırmak ve istihdam yaratmak gibi amaçların gerçekleştirilmesinde, mahalle kavramı ve mahallenin bileşenlerinin, ulaşımda yayalara ve bisiklete öncelik veren entegre ulaşım sistemleri ile desteklendiği görülmektedir.

Kendine yeterli bir kent olması hedeflenen eko-kentte, yeni bir kent ve komşuluk kültürünün oluşturulması amaçlanmıştır. Diğer yandan, kendi içinde bir merkezi olmasına rağmen, Bursa kent merkezi ile bağlantı kurmak üzere, yüksek altyapı ve çevre standartlarına sahip olması amaçlanmıştır (TBB, 2017a). 


\section{Eskişehir-Süper Kent Projesi}

Çevre ve Şehircilik Bakanlığı ve İstanbul Teknik Üniversitesi işbirliği ile planlanan Eskişehir-Süper Kent Projesi'nde, afet riski altındaki belirli özelliklere sahip alanların dönüşümünde, sürdürülebilirlik ilkelerinin göz önüne alındığı öncü bir perspektife sahip "ekolojik yerleşme birimleri" eldeedilmesi amaçlanmıştır.

Temel uygulama alanlarında (arazi kullanımı ve kentsel tasarım, enerji, su, ulaşım, malzeme ve kaynaklar, sosyal ve ekonomik sürdürülebilirlik) geliştirilen asgari ölçütleri ve performans ölçütleri ile değerlendirme imkanı sağlayan kentler oluşturulması amaçlanan proje, Sürdürülebilirlik Performanslı Kentsel Dönüşüm (Süper Kent Sistemi) olarak adlandırılmıştır. Proje için 838 hektarlık alan belirlenmiş ve 75 bin kişinin yaşayabileceği öngörülmüştür.

Projede, yerleşim alanı içinde yaşayan toplulukların 'karbon ayak izlerinin', standart yerleşim alanlarından daha az olması için sera gazı emisyonu azaltılmaktadır. Bu şekilde, daha kaliteli ve sağlıklı bir kentsel yaşam tarzının oluşturulması yanı sıra enerji, su ve doğal kaynakların kullanımı bakımından yüksek ekonomi sağlanmaktadır. Proje kapsamında enerjinin verimli kullanımı için enerji verimli yapılara yer verilirken, karma kullanım ile soğutulan yapıların ürettiği atık ısıyı değerlendiren, kendi enerjisini yenilenebilir kaynaklarla üreten, depolayan, kullanan, doğru akım kullanan gereçler için de tesisat şartları oluşturulmaktadır.

Aynı zamanda, suyun verimli kullanımı için, evsel ve yağmur sularını ayrık sistemde toplayan, evsel atık suyunu arıtan, atık suyu (gri su) ve yağmur suyunu geri kazanan ve yeniden kullanan sistemler oluşturulmaktadır. Kendi iş olanaklarını ve donatılarını yaratan projede yeşil alan ve kentsel tarım alanı temin edilmektedir. Donatılara, ticaret ve iş yerlerine yaya ve bisiklet yolları ve toplu taşım ile erişebilirlik sağlanmaktadır. Fosil yakıtlı bireysel araç kullanımı sınırlanmaktadır. Dönüşümden kaynaklı inşaat atıklarının ve diğer muhtelif atıkların değerlendirildiği uygulamalar teşvik edilmektedir.

Süper Kent Sistemi ile minimum \%44 daha düşük işletme gideri, \%44 daha düşük kamu gideri, \%65 enerji verimliliği, \%65 su tasarrufu ve \%55 işletme verimliliği elde edilecek ve proje 14. yıldan itibaren kamuya kar sağlamaya başlayacaktır. Süper Kent ile elde edilecek bu tasarruf potansiyelinin minimum seviyede kabul edildiği ve özellikle yenilenebilir enerji kaynakları ile birlikte düşünüldüğünde tasarrufun çok) daha yüksek rakamlara ulaşması beklenmektedir (CSB, 2018). 


\section{Konya-Bizim Şehir Projesi}

"Bizim Şehir Projesi-Konya”, T.C. Çevre ve Şehircilik Bakanlığı tarafından yürütülen Konya İli, Selçuklu İlçesi içerisinde 350 hektar büyüklüğündeki alan üzerinde uygulanacak bir pilot projedir. Şehirlerin bütüncül bir tasarım ve disiplinlerarası bir çalışma yaklaşımı ile yeşil, güvenli, insan odaklı, kimlikli ve akıllı şehir konseptlerini bir arada bulundurarak planlanabilmesi için gerekli olan tasarım çalışmalarının yapılması, bir yol haritası oluşturulması ve uygulamaya koyulabilen planlama-tasarım yaklaşımı oluşturulması için başlatılan bir çalışmadır. Planlama, kentsel tasarım, karar alma ve uygulama süreçleri ile ilgili çalışmalar devam etmektedir.

\section{Gaziantep Eko-Kent Projesi}

Gaziantep Eko-Kent Projesi ilk olarak, ekolojik bir yerleşme modeli oluşturması, uygulamaya yönelik örgütlenme şemasının ve imar planlarının genel ilkelerinin belirlenmesi amacıyla Ekoloji Odaklı Vizyon Planı çalışması ile başlamıştır. Hazırlanan Gaziantep Kilis Yolu ve Çevresi Vizyon Planı yaklaşımı ile ekolojik dengenin korunması, doğal kaynakların sürdürülebilir kullanımı, toprak, su ve havayı yaşatmak, flora ve fauna varlığını korumak, organik tarımı geliştirmek, enerji etkinliği ve verimliliği, yeşil alan sürekliliği ve çeşitli kültürel yapılanmalarla bölgenin cazibe merkezi olması hedeflenmiştir.

Ekokent alanındaki yapılaşmanın ise, ekolojik, çevreye duyarlı, minimum enerjiye ihtiyaç duyan, iyi yalıtımlı, atıkların yönetildiği, doğal ve aktif sistemlerle ısınma ve aydınlatma için gerekli enerjileri sağlayabilen ve yapılacağı arazi üzerindeki yeşil dokuyu koruyan ve/veya geliştiren bir şekilde gerçekleşmesi için bir teşvik mekanizması oluşturulmuştur. Bu doğrultuda bazı kriterlerin belirlenmesi adına yapılaşmaya yönelik Ekolojik Kentsel Tasarım Rehberi oluşturulmuştur.

\section{Değerlendirme ve Sonuç}

Ekonomik büyüme odaklı kalkınmanın doğal çevreye verdiği tahribatların günümüzde tüm dünyayı tehdit eder hale gelmesi nedeniyle ortaya çıkan sürdürülebilir kalkınma yaklaşımları, zaman içerisinde kentsel alanlardaki sorunlara daha fazla dikkat çekilmiştir. Bu makale, sürdürülebilir kentlerin ve kentleşme biçimlerinin nasıl gerçekleştirileceği konusunda gerek akademik yazında gerekse ulusal-uluslararası politika düzeylerinde geliştirilen yaklaşımları irdelemiş ve bunlar arasından ekolojik planlama yaklaşımına 
odaklanmıştır. Elde edilen bulgulara göre tüm dünyada sürdürülebilir kentlerin oluşturulması için yaşanan geçiş sürecinde, kentleşme biçimi, sürdürülebilir bir kent oluşumu ve planlamasına dair uzlaşılmış bir model henüz bulunmamaktadır.

Bununla birlikte, bu makalede incelenen yeni şehircilik, akıllı büyüme ve ekolojik kentleşme yaklaşımlarına göre, temiz, yeşil ve sürdürülebilir bir kent üretmek amacıyla, doğayı insan ihtiyaçları için kullanıp tüketmek yerine doğa ile işbirliği yaparak, doğaya uyumlu tasarım ve planlama stratejileri üretilmelidir. Ayrıca, ütopik olmayan, uygulanabilir projelerin hayata geçirilmesi için kamu politikaları ile desteklenen güçlü ve bütüncül bir yönetim organizasyonu ile ulusal akımlar oluşturulması ve toplumsal bilincin yükseltilmesi gerekmektedir.

İncelenen bu yaklaşımların, genellikle derişiklik (kompaktlık), sürdürülebilir ulaşım, yoğunluk, çeşitlilik, karma arazi kullanımı, pasif enerji kullanımı ve yeşil tasarım gibi temel ilkelere başvurduğu gözlenmiştir. Akıllı büyüme ve yeni şehircilik akımları, genellikle kentin büyümesi ve mevcut yerleşme birimlerinde mahalle düzeyinde geleneksel kent dokusunda sürdürülebilirlik yönünde değişim ve dönüşümle ilgilenmektedir. Ancak, ekolojik planlama yaklaşımının, diğer yaklaşımların ortak noktasını oluşturmasına rağmen, uygulamada tek bir model bulunmadığı görülmektedir. Yine de, ekolojik planlamada genel olarak, doğal çevreye ve doğaya uyumlu yaşam tarzına hassasiyetlerin daha yüksek olduğu söylenebilir.

Ekolojik planlamaya dair örnekler incelendiğinde, dünyada iki tür ekolojik kentleşme yaklaşımı bulunduğu görülmektedir. Bunlardan ilki eko-kentlerin kurulmasıyla ilgiliyken, diğeri mevcut kentsel çevrelerin ekolojik ilkeler doğrultusunda dönüşümünü hedeflemektedir. Mevcut kentsel alanlarda, atık yönetimi, yenilenebilir enerji, yeni nesil teknoloji, sürdürülebilir ulaşım (yaya öncelik ve toplu taşıma odaklı), yeşil alanların miktarının arttırılması gibi konular öne çımaktadır.

Diğer yandan, eko-kent örneklerinin mevcut kentsel alanlar yerine, kentin dışında büyük alanlarda uydu kentler olarak planlandığı görülmekte, mevcut kentle etkileşiminin zamanla sağlanacağı düşünülmektedir. Ancak, uygulanabilir eko-kent planları için, sadece çevrenin değil, ekonomi ve toplumun da birlikte ele alındığı bütüncül yaklaşımlara gereksinim bulunmaktadır. Ekolojik boyutları sadece ekonomik yönleriyle ele alan bir eko-kentin gerçekleştirilmesi ve/veya devam ettirilmesi yönünde zorluklara rastlanmıştır. Örneğin, bu kentlerde ve/veya kent parçalarında kimlerin yaşayacağı, bu kişilerin nasıl yerleştirileceği gibi sorunlar karşımıza çıkmaktadır. 
Diğer yandan, mevcut kentsel alanlarda ekolojik planlamaya geçişin nasıl olacağı daha büyük bir sorundur. Benzer biçimde, ülkemizde de yurtdışı örneklerine benzer eko-kentlerin kurulması için planlar ve projeler geliştirilmektedir. Ancak, ülkemizin geçirdiği hızlı kentleşme süreciyle biçimlenen ve çoğu zaman düşük standartlardaki yapı stoğuna ve donatılara sahip mevcut kentsel alanların, sürdürülebilir ve/veya ekolojik kentsel alanlara nasıl dönüşeceği önemli bir sorundur ve bu konuda önerilerin geliştirilmesine ihtiyaç duyulmaktadir.

Bu bağlamda, eko-kentlerin temel ilkeleri ile ekolojik planlama yaklaşımlarının ilkeleri doğrultusunda bir yol haritası geliştirilmesine ihtiyaç duyulduğu görülmektedir. Günümüzde mevcut kentsel alanlarda sürdürülebilirlik ve ekoloji yaklaşımının kentin tüm bileşenlerine entegre edilebilmesi için, bu olguların bütüncül bağlamda kent yönetimi ve politikalarında, kentin planlama ve tasarımında, kurumsal-toplumsal ve bireysel ölçekte geliştirilecek çözümlerle gerçekleştirilmesine gereksinim bulunmaktadır.

Planlamada belirlenen hedeflerin somut gerçeklere dönüşmesi ve uygulanabilir olması gereklidir. Her ne kadar eko-kent örnek uygulamalara gereksinim duyulsa da, ekolojik planlama ilkelerinin, mevcut kentsel alanlara uygulanabilirliğini sağlamak üzere dünyada yerel topluluk programları yoluyla bazı adımlar atıldığı görülmektedir (Elariane, 2012). Bu makalenin inceleme konusu dışında kalan bu uygulamalar, mevcut kentlerin de zamanla ekolojik kent ilke ve kriterlerine uygun şekilde değişimi ve dönüşümünü gerçekleştirmeyi hedeflemektedir.

Sonuç olarak, ülkemiz mevcut kentsel alanlarını sürdürülebilir ve ekolojik planlama ilkeleri doğrultusunda irdelemek ve geliştirmek için, eko-kentlerin kurulmasının yanı sıra, mevcut kentsel alanların da ekolojik alanlara dönüştürülmesi için, yerel topluluk düzeyinde planlama standartlarının ve niteliksel değerlendirme ölçütlerinin geliştirilmesine gereksinim olduğu görülmektedir. Bu makalede incelenen örnekler arasında, kent içindeki mevcut alanların dönüşümüne yönelik geliştirilen Eskişehir Süperkent Projesi'nde önerilen performans kriterlerinin ve benzer yaklaşımların, ülkemizdeki mevcut kentsel alanlarda da kullanılabilir hale getirilmesi önemli bir gereksinimi karşılayacaktır. 


\section{Extended Abstract}

\section{Ecological Planning and Eco-Cities As a Sustainable Urbanization Approach}

\author{
Hayriye Eylül Kaya \\ ORCID: 0000-0003-3287-4493
}

\author{
Arzu Taylan Susan \\ ORCID: 0000-0001-5718-8794
}

Developments in the economy and technology have changed the growth forms of cities by leading a huge migration into cities and rapid growth of urban areas. To meet the needs of the increasing population, cities expand in terms of fringes and sprawls. This caused to lose the fertile agricultural lands in their environment, on one hand. The ascending use of individual cars in expanding cities, on the other hand, has led to increase in the carbon footprint and climate change. In this context, protection of the scarce natural resources and their transfer into future generations have become increasingly vital, when sustainable urbanization approaches are required to prevent the uncontrolled and rapid development of cities.

Sustainable cities are also the places of higher level of livability, where the future generations will confront with healthy living environments. Thus, the new urbanization movements and approaches, which have emerged in several countries such as smart growth, green urbanism, new urbanism and ecological planning, have also spread across the world. These approaches aim fundamentally to control the development and expansion of cities and to produce healthy and naturally adaptive urban environments with higher quality of life. The objective of effective global scale solutions of these approaches led them to deal with local scale implementations, particularly in neighborhoods. In this context, this article reviews these sustainable urbanization approaches from their historical roots, i.e. first ecological approaches such as Howard's Garden City Utopia and Neighborhood Planning, to recent flows such as New-traditional Planning, Smart Growth and Eco-urbanization in terms of their principles on urban development and form. 
In more detail, this article explores the Garden City Model that integrate characteristics of rural and urban areas in terms of including green areas in the middle-intensity and limited sized settlements, the Neighborhood Model that includes low-intensity living areas with safer pedestrian ways and allows interaction of public utilities and neighborhoods, New-Traditional Planning approach that promotes mixed-used development and higher intensity as well as increasing aesthetic values to encourages walking, Smart Growth approach that defends compact urban form, which aims effective use of energy and environmental potentials in terms of sensitive growth, intensive building design and higher intensity, and the Ecological Planning approach, which constitutes the common principles of these approaches as well as implementation policies.

The common principles of these approaches, which include compactness, sustainable transportation, intensity, diversity, mixed-land-use, green design and passive energy use, are all encompassed in the Ecological planning approach, which focuses on reduction of the carbon footprint and low carbon developments through the smart and effective use of resources as well as integrating technology due to its motivating reason, i.e. climate change. This article explores firstly these common concepts and principles, which take place in the ecological planning, with their principles and roots in a historical perspective. Then, the article examines the Eco-city examples in the World such as Masdar City, Tianjin, Astana as well as in turkey such as Bursa Nilüfer Eco-city, Eskisehir Super-City, Konya Our-City and Gaziantep Eco-City by comparing their planning and implementation. Based on findings, although these eco-cities have fundamental objectives, each of them has focused on different subjects. Therefore, they contribute to eco-urbanization in diverse aspects, which varies with their progress in featured subjects, that can influence the global society beyond neighborhood scale. Turkey is observed as integrating ecological planning approaches into planning policies that steering the city form. The implemented examples and planned projects reveal that adaptive and coordinating efforts among scales and sectors are required to obtain sustainable communities.

The implementation of eco-city plans do not only require addressing the environment, but also economy and society in comprehensive perspectives. To develop and transform the exiting urban areas in the framework of sustainable and ecological planning principles in our country, it is necessary to develop planning standards and qualitative evaluation measures at the community level. The findings of this article, which include principles and models to plan 
sustainable and ecological cities, are expected to contribute into planning processes and policy-makers for implementation of eco-city projects as well as the transformation of existing urban areas into ecologic and sustainable directions.

\section{Kaynakça/References}

Adil, S. (2010). Ekolojik kentleşme ve toplu konutlarda ekolojik planlama yaklaşımının Başakşehir 4. Etap örneğinde incelenmesi. Bahçeşehir Üniversitesi Fen Bilimleri Enstitüsü, İstanbul.

Akgül, Ö. D. (2012). Ekokent tasarm kriterlerinin sürdürülebilirliğe etkisi: Malmö-bo01 ve Ecoviikki örnekleri bağlammnda bir değerlendirme. Mimar Sinan Güzel Sanatlar Üniversitesi Fen Bilimleri Enstitüsü, İstanbul.

Aklanoğlu, F. (2009). Geleneksel yerleşmelerin sürdürülebilirlĭgi ve ekolojik tasarm: KonyaSille örneği. Ankara Üniversitesi, Fen Bilimleri Enstitüsü, Ankara.

Aydın, B. (2010). Gelişme alanlarnnda ekolojik kentsel yerleşim kriterlerinin belirlenmesi ve imar planı kapsamında yorumlanması: Ömerli Havzası-Sancaktepe Örneği. İstanbul Teknik Üniversitesi, Fen Bilimleri Enstitüsü, İstanbul.

Aydın, B. Tezer, A. (2011). İmar Planları ekolojik planlamaya adapte edilebilir mi. Ekoyap Dergisi, 3, 100-105.

BM (Birleşmiş Milletler) (2017). Yeni kentsel gündem [online], Habitat III. 3 Haziran 2019 tarihinde http://habitat3.org/wp-content/uploads/NUA-Turkish.pdf adresinden erişildi.

BM (Birleşmiş Milletler) (2018). Sustainable development goals 2018. 3 Haziran 2019 tarihinde https://sustainabledevelopment.un.org/sdg11 adresinden erişildi.

BM (Birleşmiş Milletler) (2018). Sustainable development goals report 2018. 3 Haziran 2019 tarihinde https://unstats.un.org/sdgs/report/2018 adresinden erişildi.

Chhetri, P. Han, J. H. Chandra, S. Corcoran, J. (2013). Mapping urban residential density patterns: Compact city model in Melbourne, Australia. City, Culture and Society, 4 (2), 77-85.

Çahantimur, A. (2007). Sürdürülebilir kentsel gelişmeye sosyo-kültürel bir yaklaşım: Bursa Örneği. İstanbul Teknik Üniversitesi, Fen Bilimleri Enstitüsü, İstanbul.

Çalışkan, O. (2004). Sürdürülebilir kent formu: derişik kent. Planlama Dergisi, 3, 33-54.

Çalışkan Samur, D. (2010). Sürdürülebilir ekolojik kentsel yerleşmelerde açı alanların önemi ve İstanbul'da eko park öneri alanları: Pendik, Sultangazi ve Fatih. Bahçeşehir Üniversitesi Fen Bilimleri Enstitüsü, İstanbul.

Çetinkaya, Ç. (2013). Eko-Kentler: Kent ve doğa ilişkisinde yeni bir sistem tasarımı. Türk Bilimsel Derlemeler Dergisi, 1, 12-16.

Çevre ve Şehircilik Bakanlığı.(2015). Sürdürülebilirlik performansll kentsel dönüşüm (Süper Kent Sistemi) Projesi 10 Haziran 2019 tarihinde http://altyapi.csb.gov.tr/surdurulebilirlik-performansli-kentsel-donusum-super-kent-sistemi-projesi-haber-20704 adresinden erişildi. 
Elariane, S. A. (2012). Neighborhood urban quality of life: Guidelines for urban planning and development of new assessment tool. PhD,Faculty of Engineering, Cairo University.

Ercoşkun, Ö. Y. (2018). Sürdürülebilir kentsel planlama ve tasarm: Dünya örnekleri.

Eryıldız, S. Xhexhi, K. (2011). “Eco Cities” under construction. Gazi University Journal of Science, 25 (1), 257-261.

Farr, D. (2008). Sustainable Urbanism. Urban Design with Nature,4-21

Gaffron P, Huismans G. Skala F. (2005). ECOCITY Book I A better place to live. Edinburgh.

Gaffron P, Huismans G. Skala F. (2005). ECOCITY Book II How To Make ItHappen. Austria.

Gül, A. ve Polat, E. (2002). Kentlerin geleceği için bir zorunluluk; Bütüncül ekolojik yaklaşım.

Işıldar, G. Y. (2012). 2011 Avrupa yeşil başkenti Hamburg: Eko-kent Kriterleri Ve Performans Göstergeleri Açısından İncelenmesi. Sosyal Ekonomik Araştırmalar Dergisi, 12 (23), 241-262.

Jabareen, Y. R. (2006). Sustainable urban forms: Their typologies, models, and concepts. Journal of planning education and research, 26 (1), 38-52.

Kaptan, H. (2018). Bursa Nilüfer Belediyesi Nilüfer Ekokent Projesi Plan Raporu, 65.

Kaypak, Ş. (2011). Küreselleşme sürecinde sürdürülebilir bir kalkınma için sürdürülebilir bir çevre. KMÜ Sosyal ve Ekonomik Araştırmalar Dergïi,13 (20): 19-33.

Lynch, K. (1984). Good city form. MIT press.

Manisalı, N. (2011). Ekolojik Yerleşimler üzerine bir değerlendirme:İstanbul'dan örnekler.

Nedovic-Budic, Z. Knaap, G. J. Shahumyan, H. Williams, B. ve Slaev, A. (2016). Measuring urban form at community scale: Case study of Dublin, Ireland. Cities, 55, 148164.

Önder, S. Kurtaslan, B. Ö. (2009). Kent planlamaya ekolojik yaklaşımlar ve Konya kenti yeşil kuşak örneği. Selçuk Tarım ve Gida Bilimleri Dergisi, 23 (47), 56-62.

Özcan, A. (2007). Ekolojik temele dayalı sürdürülebilir kentsel gelişme: Malatya Kent Örneği üzerinden bir değerlendirme. ICANAS Uluslararası Asya ve Kuzey Afrika Çalışmaları Kongresi, 10-15.

Sağ, N. S. (2011). Dönüşüme bağh kentsel gelişmenin yönetilmesinde bir araç olarak akıllı büyüme; Konya kenti örneği. Selçuk Üniversitesi Fen Bilimleri Enstitüsü, Konya.

Sharifi, A. (2016). From garden city to Eco-urbanism: The quest for sustainable neighborhood development. Sustainable Cities and Society, 20, 1-16.

TBB, (2017a). Sürdürülebilir ekolojik kentsel gelişim yaklaşımı belediyeler için rehber. 16 Temmuz 2019 tarihinde www.tbb.gov.tr/online/kitaplar/surdurulebilir_kentsel_ekolojik_gelisim_2017/html5forpc.html adresinden erişildi.

TBB, (2017b.) Yeni kentsel gündem Habitat III. 16 Temmuz 2019 tarihinde www.tbb.gov.tr/online/kitaplar/surdurulebilir_kentsel_ekolojik_gelisim_2017/html5forpc.html adresinden erişildi.

Tosun, K. E. (2013). Sürdürülebilir kentsel gelişim sürecinde kompakt kent modelinin analizi. Dokuz Eylül Üniversitesi Sosyal Bilimler Enstitüsü Dergisi, 15 (1), 103-120. 
Tosun, E. K. (2017). Sürdürülebilirlik bağlamında ekolojik kent söylemi. Abant İzzet Baysal Üniversitesi Sosyal Bilimler Enstitüsü Dergisi.

Van Kamp, I. Leidelmeijer, K. Marsman, G. ve De Hollander, A. (2003). Urban environmental quality and human well-being: towards a conceptual framework and demarcation of concepts; a literature study. Landscape and Urban Planning, 65(1), 5-18.

Yazar, K. H. (2006). Sürdürülebilir kentsel gelişme çerçevesinde orta ölçekli kentlere dönük kent planlama yöntem önerisi. Ankara Üniversitesi, Sosyal Bilimler Enstitüsü, Ankara.

Yigitcanlar, T. Lee, S. H. (2014). Korean ubiquitous-eco-city: A smart-sustainable urban form or a branding hoax?. Technological Forecasting and Social Change, 89, 100-114.

Wheeler, S. M. (2013). Planning sustainable and livable cities, Equitable and Ecological Communities. London: Routledge

Waite,G. (2019), Top 10 eco-friendly cities around the world. 1 Ağustos 2019 tarihinde https://www.openaccessgovernment.org/top-10-eco-friendly-cities-around-theworld/53998/ adresinden erişildi. 